NBER WORKING PAPERS SERIES

MONEY, INTEREST AND PRICES

Stanley Fischer

Working Faper No. 3595

NATIONAL BUREAU OF ECONOMIC RESEARCH

1050 Massachusetts Avenue

Cambridge, MA 02138

January 1991

This paper is part of NBER's research program in Economic Fluctuations. Any opinions expressed are those of the author and not those of the National Bureau of Economic Research. 
NBER Working Paper \#3595 December 1990

MONEY, INTEREST, AND PRICES

\begin{abstract}
Twenty five years after the publication of the second edition, this paper describes and evaluates the contributions to monetary and macroeconomics made in Don Patinkin's Money, Interest, and Prices (MIP). Its first accomplishment was to settle definitively many issues, such as the valid and invalid dichotomies between real and nominal magnitudes, Say's identity, the nature of the Keynesian system, and the requirements for the neutrality of money, which had been disputed for decades. It also opened the road to the future by developing macroeconomic models from a well specified microeconomic foundation. In so doing, it established the base on which subsequent equilibrium macroeconomics built. Beyond that, in chapter XII, Patinkin pioneered the development of disequilibrium analysis by presenting a fully articulated model that makes the key distinction between notional and effective demands, and using it to explain price and quantity adjustments in conditions of unemployment.

Stanley Fischer E52-280A, MIT Cambridge, MA 02139
\end{abstract}




\section{MONEY, INTEREST, AND PRICES}

Stanley Fischer ${ }^{*}$

Twenty five years after the publication of the definitive second edition of Money, Interest, and Prices (MIP), and thirty four years since the thirty four year old author published the first edition, we meet to honor Don Patinkin. We will honor him most in discussing his major scientific work its contents, its impact, and its contributions - by trying to emulate the objectivity and careful scrutiny to which Patinkin subjects the work of others. ${ }^{1}$

\section{The Book}

The structure of MIP remains essentially unchanged between the first and second editions. Part I - "Microeconomics" - develops the demand functions of an individual who makes allocation decisions weekly, and, for the early parts of Part I, can carry wealth between weeks only in the form of money. Part II - "Macroeconomics" - uses macroeconomic models built on the microeconomic foundations of Part I to examine the major issues in monetary and macroeconomic theory. Part II is also notable for the disequilibrium model set out in Chapter XIII, a model which goes far to make sense of the Keynesian model and which contains the essential idea of the later disequilibrium approach to macroeconomics. ${ }^{2}$

The subtitle of the book, "An Integration of Monetary and Value Theory," emphasizes Patinkin's overall purpose, which is to ensure that the role of money is fully explicated and developed within the context of the standard model of the optimizing household, and in analyzing the forces that produce and maintain market equilibrium.

\section{a. Part I}

Part I opens with a brief exposition, in Chapter I, of the Hicksian model of the consumer in a barter economy. Patinkin moves quickly in Chapter II to include money, which is held because purchases

* Department of Economics, MIT. This paper was written when I was on leave from MIT, as Chief Economist at the World Bank. I am grateful for comments on an earlier draft by Peter Howitt, Lawrence Klein, David Laidler, and Paul Samuelson, and for assistance from Peter Pedroni and Gunnar Eskeland of the World Bank.

1 References are to the second (1965) edition, unless stated otherwise.

2 See, for example, the survey in Drazen (1980). 
and sales of goods are not coordinated. Since money is carried from period to period, real money holdings at the beginning of a period are part of the week's "income," and as such enter the individual's demand functions for goods, and for real balances.

Because the individual carries nominal balances from period to period, any change in the aggregate price level generates a wealth effect that affects the demand for goods and the demand for money. This is the real balance effect, the key to the integration of monetary and value theory. ${ }^{3}, 4$

Patinkin begins to use his apparatus to good effect in Chapter II (see in particular Figure II-2, p. 29), where he disposes of the contention of many earlier quantity theorists that the demand for money (with the quantity of money on the horizontal axis and the inverse of the price level on the vertical axis) is a rectangular hyperbola. In an "individual experiment," the effect of an increase in the price level on the individual's demand for nominal balances is examined, holding constant

3 Johnson (1962) draws attention to the awkwardness of the Hicksian week construction that adds the stock of money and the flow of income to define the individual's weekly "income." (Johnson charged Patinkin with a dimensional error in adding the flow of income and the stock of money; Patinkin responded with Mathematical Appendix 11 in the second edition, which shows that there is no error. The construction is, however, awkward.) As discussed by May (1970) and used by Sidrauski (1967) and many others, two separate constraints are operable in the continuous time limit: the stock constraint, constraining the changes in asset holdings that an individual can undertake at a moment of time, and the flow constraint, describing the relationship among income, saving, and consumption. More fundamentally, if the individual can lend and borrow freely, there is only a single present value budget constraint, in which the present value of consumption has to be equal to the value of the individual's asset holdings plus the present value of non-asset income. (It may be necessary to supplement the present value budget constraint with a transversality condition, or some other condition that prevents Ponzi games.) In any case, Patinkin's emphasis on the real balance effect as the link between the stock of money and the goods markets is not affected by shifting to a continuous trading model: it is still true that a change in the price level generates a change in wealth that affects the demand for goods - which is the essence of the real balance effect.

4 Of course, in the presence of other nominal assets, a change in the price level may produce wealth effects that extend beyond the real balance effect. In Chapter XII Patinkin discusses whether individuals discount future tax liabilities, and thus whether a wealth effect is generated by the impact of a change in the price level on the real value of government nominal bonds. He assumes that there is a wealth effect, while introducing a parameter that allows for some discounting of future tax liabilities. 
the real value of other income and the nominal stock of initial balances. An increase in the price level reduces real wealth and therefore the demand for real balances: accordingly the demand for nominal balances will rise by less than the price level. Thus in an individual experiment the demand for nominal money balances (as a function of the price level) is less than unit elastic. One can also trace out a "market experiment" curve, which shows the equilibrium price level that obtains for alternative quantities of money is changed. In an economy in which money is neutral, ${ }^{5}$ this curve is a rectangular hyperbola.

Another aspect of the integration of monetary and value theory emerges in Chapter III, which examines the effects on the economy of a change in the quantity of money. Here Patinkin insists on examining not only the comparative statics of the change, but also the economic forces that bring about a change in the price level - which, in a model without a bond market, can only be the real balance effect operating in the goods market. In the second edition, Chapter III is extended to deal with the Archibald-Lipsey (1958) criticism of the analysis of the dynamic effects of a change in the quantity of money in the first edition. ${ }^{6}$ In the first edition of MIP, Patinkin confined his analysis of the effects of a change in the quantity of money to the week in which that change occurred, and stated that money would be neutral if there were no distribution effects, ${ }^{7}$ for example if each individual's money holdings were increased in the same proportion. Archibald and Lipsey extended the analysis over time, and showed that under reasonable assumptions, the long-run equilibrium of the economy would exhibit neutrality of money even if there were distribution effects: the redistributions of cash balances among individuals from week to week ultimately reproduce the initial pre-disturbance distribution of real balances. Patinkin adds such an intertemporal analysis, but argues convincingly that it does not invalidate his earlier conclusions. ${ }^{8}$

Bonds make their appearance in Chapter IV, which also extends the analysis to a production

5 The conditions for neutrality will be discussed below.

6 This is a real-time intertemporal analysis, showing how the price level changes from week to week, rather than the a-temporal "stability" analysis that examines the forces that determine the price level within each week.

7 This is a necessary, but not sufficient, condition for neutrality.

8 A modern analysis would lay far more stress on expectations than either Archibald and Lipsey or Patinkin did. However, the dynamic adjustment to a redistribution of initial money holdings would not normally be complete within a single week in the framework of the Patinkin model even if expectations were rational. 
economy. At the same time Patinkin lengthens the horizon of the individual to more than one week. This forces him to be more specific about the motives for holding money, and leads into an extensive analysis in Chapters V-VII (of the second edition) of the demand for money and bonds.

Patinkin regarded the extended analysis of asset demand presented in Chapters V-VII of the second edition as the major improvement over the first. ${ }^{9}$ The demand for money as the means of payments is analyzed in Chapter V, building on a stochastic payments model developed (in the first edition) by Patinkin, the statistical properties of which were further developed by Aryeh Dvoretzky. ${ }^{10}$ Patinkin argues for attributing utility to the holding of real balances, dismissing the charge that this practice is purely circular. In the new introduction to the abridged second edition $(1989)^{11}$ he also indicates his preference for the utility approach over the Clower constraint, a judgment that I share, but one on which it is hard to be absolutist since in many circumstances the practices are equivalent and the issue is only one of the specificity of the modelling of money demand. Using the marginal utility approach, Patinkin works out and graphically illustrates the consumer's first order conditions for money and bond holdings, and the implied theory of saving. The graphs of Chapter V, and even more those of Chapter VI, are complicated; the author's insistence on keeping most of the mathematical details in appendices is one of the relatively few marks of the vintage of the book.

Chapter VI is described as developing the precautionary and speculative motives for holding money and bonds, although Chapter V's stochastic payments model can also be thought of as generating a precautionary demand for money. ${ }^{12}$ Chapter VII shows that the essential properties of the demand for money function are not much affected if money is viewed as a producer's good. Most of the revision of Chapters V-VII between the first and second editions reflects theoretical developments by Tobin (1958) and Markowitz (1959) that brought uncertainty firmly into the fold of economic and monetary theory.

Throughout the first seven chapters, Patinkin uses the models he is developing to clarify and

9 In the preface to the second edition, he describes this as the "principal difference" (p. xiv); it is safe to assume he also saw it is as the major improvement.

10 See the Special Appendix to Chapter V, pp. $450-456$.

11 The abridgement is achieved by omitting the "Supplementary Notes and Studies in the Literature."

12 I am grateful to David Laidler for this point. 
resolve outstanding issues. Beyond the theme of the integration of monetary and value theory, he repeatedly shows the validity of the quantity theory: that under well-defined conditions, changes in the quantity of money are neutral, equivalently that an increase in the stock of money leads to an equiproportionate change in the price level.

Several of the long - time controversial issues in monetary theory are brought together in the last chapter of Part I, Chapter VIII, "A Critique of Neoclassical Monetary Theory." Much of this chapter will strike today's reader as dealing with outmoded questions. But that is in large part because the critique of the previous literature is definitive: for instance, it was not possible later to commit the "invalid dichotomy" of treating the real economy as if it determines relative prices and the monetary economy as if it determines the aggregate price level without being aware of the $\sin$.

Archibald and Lipsey (1958) and other critics of the first edition had shown that it was possible to construct a mathematically consistent dichotomized model that produces the same comparative statics results as a model that includes the real balance effect. Patinkin correctly countered that the issue is not mathematical consistency, but economic consistency: models of that type contain no economic description of how or why the economy moves from one equilibrium to another when the quantity of money changes, or of the forces maintaining the economy in equilibrium. However, he notes that there is a valid dichotomized model in which the real balance effect does not have to appear directly in the goods markets: there are no economic inconsistencies in a model in which an increase in the stock of money has a real balance effect only in the bond market, driving down the interest rate, which in turn affects the demand for goods and thus the price level. Such a model is close to the thinking expressed in the standard textbook exposition of the monetary mechanism, in which changes in the stock of money first create portfolio disequilibria, which affect rates of return, which in turn affect flows of spending.

Patinkin presents eight arguments in Chapter VIII to establish that neoclassical monetary theorists did not fully understand the real balance effect. His indictment is persuasive, as is his conclusion that his work improves their theory rather than destroys it, and that these economists would have accepted Patinkin's amendments to their theories if they had had the opportunity to do so (p. 188). This seems to put Patinkin very close to Samuelson (1968), who complains that Patinkin's reading of the earlier theorists is not sympathetic. ${ }^{13}$ Many readers, this one included,

13 Samuelson asks rhetorically in what sense a writer can be said to believe one thing and write another. His answer, he admits, is non-operational: the author, when presented with what he has written and what he is believed to believe, would prefer the latter. In responding to Samuelson, Patinkin (1972, pp. 282-283) points out that Samuelson had chaired a 1949 Econometric Society 
must have shared that sense, and wondered whether the unforgiving reading of the literature is constructive. ${ }^{14}$ Reflection suggests that it is, for two reasons: sympathetic interpretations of the literature end in speculation about what the author really meant to say, a pastime which the extensive Marxian and Keynesian literatures in that vein establish to be counterproductive; and taking the literature seriously leads, over the long run, to higher professional standards. ${ }^{15}$

Patinkin's path - breaking work, more probably than that of any other economist, is deeply rooted in the literature. The "Supplementary Notes and Studies in the Literature," mostly the latter, take up 144 pages of the second edition of MIP. Although they were omitted from the abridged second edition, they were described as "sparkling" by Kenneth Arrow (1957). The notes presage the shift in Patinkin's interests toward the history of thought, particularly the history of Keynes' thinking. ${ }^{16}$

meeting at which Hickman and Leontief apparently failed the proposed Samuelson test.

14 I do not know enough about the yeshiva tradition to know how much Patinkin's approach to the literature owes to his earlier training, for he attended a yeshiva (talmudic college) for ten years, including during his undergraduate period at the University of Chicago. One influence is visible in the first sentence of the Introduction to the book (p. xxiii): "Money buys goods, and goods do not buy money." This sentence appears to be wrong. When charged with this possibility, Patinkin replied that while it might be wrong, it was based on a talmudic saying - and led perfectly into the next sentence, the leitmotif of the book, "The natural place, then, to study the workings of monetary forces is directly in the markets for goods." [Discussion of this point with Patinkin based on the first draft of this paper, in which the part of this footnote not in square brackets appears, produced the following elucidation. The point of the talmudic discussion is to provide a rule for when a transaction is deemed to be completed. The rule is that the transaction is complete when the buyer takes possession of the object being bought, not when he pays money: "If [A] drew into his possession [B's] produce without paying him the money, he cannot retract. If he paid him the money but did not draw into his possession his produce, he can withdraw." This is expressed as "goods acquire money," which is the opposite of the opening sentence. Patinkin agrees that the allusion, and his disagreement with the talmudic rule, would not immediately be obvious to some readers.]

15 Chapter VIII concludes with a discussion of Say's Identity. There is no good reason to exhume the extensive discussion of Say's Law and Say's Identity, initiated by Lange (1942), and settled by Patinkin.

16 See, for example, Patinkin (1976) and Patinkin (1982). 
Probably the first history of thought question the typical modern reader, not as interested in the subject as Patinkin, would ask is how MIP relates to the work of Pigou, with whose name the real balance effect is also associated. Pigou (1943) used the real balance effect to argue, against Keynes and Hansen (1941), that a monetary economy does contain a mechanism that tends to produce full employment, but he did not systematically develop the implications of this effect for the integration of monetary and value theory. 17

\section{b. Part II}

"Macroeconomics" starts with four chapters examining the working of a flexible price, and therefore full-employment, macroeconomic model based on the microeconomic foundations of Part I. The model contains markets for money, bonds, commodities, and labor; by Walras' Law, only three need be considered explicitly. The model is not based exactly on the microeconomic models of Part I, which do not explicitly develop the demand for and supply of labor.

Implicit in the notion of microeconomic foundations for macroeconomics is some separation between the foundations and the macroeconomic model, as in MIP. Here the general properties of the demand and supply functions are worked out from microfoundations, but the aggregate functions are not themselves derived directly from utility and profit maximization. In current microeconomically based macroeconomics, the connection is typically much closer, the properties of the model being derived exactly from the behavior of a representative agent. The current approach ensures more faithful adherence to the underlying modelling of economic agents, frequently at the expense of having to rely on very specific assumptions in order to obtain tractable models.

The passage of twenty five years has left few marks on these chapters. Perhaps the atemporal stability analysis, which examines the forces bringing the economy into equilibrium within each week, would now be unusual. In modern practice the problem is either ignored, or - better - the decisions of price - setting agents are modelled explicitly. ${ }^{18}$

Chapter XII draws Patinkin's analysis of the full-employment model to its conclusion by

17 The relevant passage (Pigou, 1943, p. 349) is: ". . prices fall and go on falling; which is another way of saying that the stock of money, as valued in terms of real income, correspondingly rises."

18 See, for instance, some of the models presented in Blanchard and Fischer (1989), Chapter VIII. 
examining the conditions under which money is neutral. Money will not be neutral in the presence of wage and price inflexibility, money illusion (including that expressed in Keynes' original General Theory formulation of the demand for money ${ }^{19}$ ), distribution effects, and open market operations when bonds are at least in part regarded by economic agents as net wealth. The chapter concludes with an extension of the basic model to include a banking and financial intermediation system, thereby introducing the distinction between inside and outside money in the process of incorporating the contribution of Gurley and Shaw (1960). ${ }^{20}$ In discussing the indeterminacy of the price level in a pure inside-money economy, Patinkin also points to the need for the central bank to fix some nominal magnitude if the price level is to be determinate, and notes that the price level is indeterminate if the central bank operates according to the real bills doctrine, or fully accommodates union wage pressures.

A reader interested solely in the current literature would still profit from reading Chapters IX-XII; in a rush he could get most of the contents from Chapter XII. That reader would not have to read much to catch up on earlier monetary and macroconomic theory: ${ }^{21}$ Patinkin has studied the earlier literature, absorbed it, extracted most of the worthwhile contents, and disposed of the errors.

Chapter XIII, which is essentially unchanged from the first edition, breaks new ground. In dealing with the puzzle of how workers and firms behave out of equilibrium, Patinkin makes the following points about the demand for labor function: ". . . the planned labor input it specifies for any given real wage rate reflects the firms' assumptions that they will be able to sell all of their resulting output at the prevailing market price. ... Thus the influence of commodity output on labor input reflects itself, not in the variables on which the labor demand function is dependent, but

19 The reference is to Keynes' writing the demand for money function as the sum of a transactions demand, $p \bullet L_{1}\left(Y_{0}\right)$, in which there is no money illusion, and a speculative demand, $L_{2}(r)$, which is subject to money illusion. See MIP, p. 278.

20 Johnson (1962), in discussing the real balance effect, argues that "the more elegant approach to monetary theory lies along inside-money rather than outside-money lines, and that the foundation of the theory of monetary equilibrium and stability should be the substitution effect rather than the ... wealth effect of a change in real balances." It is not clear why elegance is the right criterion. What Johnson appears to be proposing is that the basic comparative static exercise in monetary theory be an open market operation, which changes the quantities of money and bonds by an equal and opposite amount, without in the first instance having a wealth effect.

21 Of course, any serious student should read the General Theory. 
in its form" (p. 319, emphases in original). Without using the terms, he distinguishes between the notions of "effective" and "notional" supply, 22 by arguing (p. 321) that even when firms in a disequilibrium situation are not producing more output than they can sell (so that there is no excess of output), there is an excess of supply, in the sense that "the optimum output they desire to supply at the real wage rate $(w / p)_{0}$ - should the market be willing to absorb this output - is still $\mathrm{Y}_{0}$," where $\mathrm{Y}_{0}$ corresponds to what we would now call notional supply. He also notes the connection between firms' behavior in labor market and the disequilibrium in the goods market: "Not being able to sell all they want, they cannot employ all they want" (p. 322). Finally, he clearly notes the "min" effective demand curve for labor, where the firm's demand for labor is the minimum of effective demand at the given real wage and the quantity of labor needed to produce the quantity of goods demanded in the goods market (p. 322).

The Patinkin analysis of the disequilibrium interaction between the goods and labor markets in generating the effective demand for labor was explicitly incorporated in the Barro-Grossman model (1971). Barro and Grossman combined Patinkin's labor market disequilibrium analysis with Clower's (1965) analysis of the distinction between the effective and notional demands for gonds. Clower's "dual decision hypothesis" was designed to explain why current income rather than the real wage might enter the consumption function: the answer is that in conditions of unemployment, when the level of income is not a choice variable, it is a constraint. One might speculate on why Patinkin, who drew the distinction between actual and desired supply, did not draw the distinction between desired and actual demand. The reason, probably, is that he started in the microeconomics part of MIP with the model of an exchange economy in which the individual's endowment of goods, the value of which is taken to be equal to "income," is exogenous, and did not amend the goods demand function in the macroeconomics part, when labor supply becomes endogenous and incom. therefore a choice variable. ${ }^{23}$

In any case, the failure to include the distinction between the notional and effective demands for goods does not invalidate Patinkin's analysis of the labor market disequilibrium and the dynamic adjustment that takes place in that market. Patinkin nonetheless felt that his analysis was incomplete, because he could not reconcile the assumption that firms could not sell as much as they wanted with

22 Patinkin uses the terms "actual" and "desired" supply, respectively.

23 Alternatively, if the individual is behaving consistently, it is always possible to write a consumption function conditional on the decision the individual has made in the labor market, and therefore conditional on the level of labor income. 
his maintained assumption of perfect competition. ${ }^{24}$ It is surprising that he did not at that point refer to Arrow's (1959) argument that it may be necessary to give up the assumption of perfect competition to develop an adequate theory of price dynamics. ${ }^{25}$ It seems clear that recent imperfect competition models ${ }^{26}$ do provide a more consistent account of price and output dynamics than the perfect competition models with an appended stability analysis that were used by Patinkin in Chapter XIII and by subsequent disequilibrium analysts.

Chapter XIV applies the analysis of the previous chapter to Keynesian macroeconomics, making the well-known (and convincing) claim that "Keynesian economics is the economics of unemployment disequilibrium" (pp. 337-338, emphasis in original). Patinkin interprets Keynes's theory of unemployment as the argument that because of distribution effects (the threat of bankruptcies in deflation) and adverse expectational effects of deflation, as well as the low responsiveness of demand to a fall in interest rates, the equilibrating powers of the real balance effect are either outweighed, or else operate so slowly, as to be of limited relevance to the political adjustment period. 27

Chapter XV, on Keynesian and Classical theories of interest, concludes the text of the book. Patinkin argues that Keynes' contention that the rate of interest is determined in the money markets is misleading, that it is in fact determined in all markets of the economy, but that secular variations in the real rate of interest have reflected technological changes rather than monetary ones. He also sides, correctly, with Hicks in dismissing the distinction between "liquidity preference" and "loanable funds" theories of interest.

24 The problem is described in footnote 9, p. 323; it is also referred to on p. 670, which describes the relationship between the first and second editions.

25 This point was made by Gogerty and Winston (1964). Patinkin (p. 670) rejects their approach as unsatisfactory, without explaining why. Possibly the reason is that while Gogerty and Winston suggest that a model with imperfect competition is needed, they do not formally develop one.

26 See footnote 17.

27 Chapter XIV concludes with discussions of the liquidity trap, Say's Identity, and secular growth versus secular stagnation. Although the simplified growth model that is introduced in the last section mentions the distinction between the real and nominal interest rates, the model is, as Patinkin (1989, p. xlii) later accepted, deficient. 


\section{c. Mathematical appendices}

The mathematical appendices are intended to be - and should be - read along with the chapters, and for the most part set out more explicitly the arguments developed in the text. While the verbal and graphical arguments in the text are generally correct, the reader frequently finds it useful to consult the appendices to clarify the argument, even, for instance, in the case of the valid and invalid dichotomies. The appendices do sometimes go beyond the text in establishing the stability of equilibria, for the graphical analysis is not always sufficient to establish stability. ${ }^{28}$

\section{d. Literature studies}

These studies range from an examination of early writings on the quantity theory, including Cantillon and Hume, to extended discussions of the work of Walras, Wicksell, and Keynes. Patinkin is especially interested in Walras' theory of money and his tatonnement process. His emphasis in MIP on the need to describe the mechanisms that cause prices to change, and that maintain equilibrium, echoes approvingly Walras' intentions in his stability analysis. Part of the reader's interest in such reviews is to see how the professor grades the students. Patinkin's approval of Walras and disapproval of Cassel are evident; he also approves (p. 164) of the monetary theory of Wicksell and Fisher, for spelling out the dynamic process by which money affects prices.

In the second edition, Patinkin added a note on empirical work on the real balance effect, quoting many studies that had found a wealth effect to operate in the consumption function. In the preface (p. xiv) he noted that there had been great progress in empirical work in this area during the past decade. This optimism about empirical work had faded by 1989 , to the point where Patinkin records his disappointment at the failure of empirical work to settle many of the apparently empirical disputes in macroeconomics $(1989$, p. xvi)

\section{Initial Review and Reactions}

There were at least twelve reviews of the first edition of MIP, almost all of them recognizing that they were dealing with a major work. In review articles in the major journals, Carl Christ in the Journal of Political Economy (1957, p. 347) described it as "an important book;" William Fellner in the American Economic Review (1956, p. 947) said the book was "a highly impressive architectonic accomplishment," concluding (p. 955) that "[i]t may be taken for granted that this

28 This was pointed out by Arrow (1957); Patinkin (1974) raised the question of when a graphical stability analysis could be used to prove, rather than suggest, stability. 
work will leave a mark on the development of economic theory;" and John Hicks Economic Journal, 1957, p. 278) argued that Patinkin had fundamentally misunderstood Keynes, a position from which he later (1967) retreated, under the force of a critique of his review by Patinkin (1959). Bent Hansen (1957) and Howard Ellis (1957) also wrote positive and lengthy review articles. Among other reviewers, Bjorn Thalberg (1960) presents a particularly thorough and accurate appraisal.

What did the reviewers find? Most of them gave primary attention to the theme of the integration of monetary and value theory, and the role of the real balance effect, and believed that Patinkin had effectively achieved his analytic goal.

Patinkin's basic argument ( $p . x x v)$ that:

The propositions of the quantity theory of money hold under conditions much less restrictive than those usually considered necessary by its advocates and, a fortiori, its critics. Conversely, the propositions of Keynesian monetary theory are much less general than the General Theory and later expositions would lead us to believe. But this in no way diminishes the relevance of Keynesian unemployment theory for the formulation of a practicable full-employment policy

is accepted by most of the reviewers, though strongly contested in Hicks' original review.

Aside from these overall themes, reviewers focus on different aspects. Some, Gudin (1957) for example, particularly welcome the microeconomic foundations of money demand; several, including Ellis (1957) welcome the distinction between individual and market experiments; many greatly appreciate the references to the literature, with Arrow (1957) singling out the literature notes for special mention; several comment on the extremely high quality of the presentation; Christ (1957) briefly and favorably comments on the disequilibrium analysis of Chapter XIII, and Hansen welcomes the disequilibrium interpretation of Keynes.

Bent Hansen's is the most detailed and most enthusiastic review, predicting that MIP "shall - or in any case should - signify the end of two decades of chaos in monetary theory. . . . When nevertheless Patinkin's contribution is so pathbreaking this is due to the fact that he - in a way not achieved hitherto - has been able to explain the connection between the quantity theory, neo-classical interdependency and Keynesian macro theory. ${ }^{29}$ The theme of the review is similar to the inset quotation from Patinkin above: that while Patinkin has rehabilitated the quantity

29 I am grateful to Gunnar Eskeland of the World Bank for revising an earlier translation, here and in the final sentence of the text of this article. 
theory, money is not in practice neutral in the relevant period. Hansen expresses a few reservations, drawing attention in particular to the endogeneity of money in a fixed exchange rate economy such as Sweden's, arguing that the equilibrating mechanisms in the system would be different (presumably than the real balance effect) if the money stock is endogenous.

After the generally favorable reviews, came a series of articles, many of them appearing in the Review of Economic Studies, that questioned and sought to develop aspects of the analysis. Archibald and Lipsey (1958) is probably the best-known of these. Archibald and Lipsey were undoubtedly right in criticizing the short-run nature of the equilibrium studied in the first edition, but, as noted above, their criticism was easily absorbed in the Patinkin framework in the second edition.

Patinkin's impact on the monetary theory of the time is visible in Harry Johnson's (1962) survey article on monetary theory. Johnson's survey deals with four broad topics: the first, the neutrality of money, is dominated by Patinkin's analysis and the controversies surrounding it. Johnson refers to MIP as "monumentally scholarly," but regards its analysis of the real balance effect as "conceptually inadequate and crucially incomplete." He attributes the inadequacies to the unsatisfactory treatment of stock-flow relationships. While there are problems in Patinkin's Hicksian week assumption, they do not invalidate the analysis of the real balance effect, as indicated in footnote 4 above.

The impact of MIP could also be judged from the reading lists of the times. I have not made a systematic search for or of such lists, but can certainly testify that in the 1960s, at the London School of Economics and at MT, the two essential books in macroeconomics were the General Theory and Money, Interest, and Prices. ${ }^{30}$

\section{A Current Appraisal}

How does MIP look twenty five years after the second edition? The advantages of hindsight and the theoretical advances of a quarter-century point to some deficiencies, several of them presented in Patinkin (1989). Most surprising from today's viewpoint, and given Patinkin's experience in the inflationary Israeli environment, is the failure to analyze ongoing inflation. Patinkin's monetary analysis is essentially comparative static, examining the effects of once-over, rather than

30 Gurley and Shaw (1960) also received considerable altention. 
continuing, changes in the price level. ${ }^{31}$ His failure to develop the distinction between real and nominal interest rates, particularly after careful study of Irving Fisher, seems surprising. Patinkin himself has commented on the (related) inadequate analysis of growth, and of his failure to examine open economy issues.

But hindsight is much too easy. The fact is that Money, Interest, and Prices stands as a gateway between the Keynesian and pre-Keynesian literatures that preceded it, and the modern literature that comes after. It did indeed put an end to two decades of chaos in monetary theory. It settled many issues, such as the dichotomies, Say's Identity, the nature of the Keynesian system, the requirements for the neutrality of money, about which the profession had been arguing for too long.

It also opened the road to the future by developing macroeconomic models from a well specified microeconomic base. The masterly analysis of the full employment models in the first four chapters of Part II not only synthesizes the best of neoclassical theory, but also goes beyond anything previously appearing in the literature. ${ }^{32}$ In so doing it established the base on which subsequent equilibrium macroeconomic analysis built. Beyond that, MIP opened the road to disequilibrium analysis by making the key distinction between notional and effective supply - even though it did not use those words - and employing the distinction to explain price and quantity adjustment in conditions of unemployment.

This is indeed a true classic. It is probably still true that this book is "the most important contribution to monetary theory published since Keynes' General Theory. ${ }^{33}$

31 The one exception is in the last section of Chapter XIV, which is however really an afterthought.

32 This is a paraphrase of the evaluation by Samuelson (1968).

33 Hansen (1957). 


\section{References}

Archibald, G. C. and Richard G. Lipsey (1958). "Monetary and Value Theory: A Critique of Lange and Patinkin," Review of Economic Studies, 26: 1-22.

Arrow, Kenneth J. (1957). "Review of Money, Interest, and Prices," Mathematical Reviews, 18 (Sept.): 8.

(1959). "Towards a Theory of Price Adjustment," in M. Abramovitz et al. (eds.), The Allocation of Economic Resources. Stanford, CA: Stanford University Press.

Barro, Robert J. and Herschel I. Grossman (1971). "A General Disequilibrium Model of Income and Employment," American Economic Review, 61 (No. 1, March): 82-93.

Blanchard, Olivier J. and Stanley Fischer (1989). Lectures in Macroeconomics. Cambridge, MA: MIT Press.

Christ, Carl (1957). "Patinkin on Money, Interest, and Prices," Journal of Political Economy, 65 (4): 347-354.

Clower, Robert (1965). "The Keynesian Counterrevolution: A Theoretical Appraisal," in F. H.

Hahn and F. P. R. Brechling (eds.), The Theory of Interest Rates. London: Macmillan.

Dieterlin, Pierre (1957). Book review, Revue Economique, No. 2: 329-331.

Drazen, Allan (1980). "Recent Developments in Macroeconomic Disequilibrium Theory," Econometrica, 48 (March): 283-306.

Ellis, Howard S. (1957). "Patinkin's Money, Interest, and Prices, " Revista Brasileira de Economia, 11:3 (read in English typescript).

Fellner, William (1956). "Patinkin's Integration of Monetary and Value Theory," American Economic Review, 46 (5): 947-955.

Gogerty, D. Calvin and Gondon C. Winston (1964). "Patinkin, Perfect Competition, and Unemployment Disequilibria," Review of Economic Studies, 31: 121-126.

Graziani, Augusto (1957). "Su Un Recente Volume di Teoria Monetaria," Giornale degli Economisti e Annali de Economia, March-April.

Gudin, Eugenio (1957) "Review Article on Don Patinkin's Money, Interest, and Prices, Revista Brasileira de Economia, 11:3 (read in English typescript).

Gurley, John G. and Edward S. Shaw (1960). Money in a Theory of Finance. Washington, DC: Brookings Institution.

Hansen, Alvin H. (1941). Fiscal Policy and Business Cycles. New York: Norton.

Hansen, Bent (1957). "Patinkin and Money - The Quantity Theory Revived?" Ekonomisk Tidskrift (read in translation).

Hicks, John R. (1957). "A Rehabilitation of 'Classical' Economics?" Economic Journal, 47 (June): 
278-289.

(1967). "The 'Classics' Again," in J. R. Hicks, Critical Essays in Monetary Theory.

Oxford: Clarendon Press.

Johnson, Harry G. (1962). "Monetary Theory and Policy," American Economic Review, 52 (June): $335-384$

Lange, Oskar (1942). "Say's Law: A Restatement and Criticism," in O. Lange et al. (eds.), Studies in Mathematical Economics and Econometrics. Chicago, IL: University of Chicago.

Markowitz, Harry (1959). Portfolio Selection. New York: John Wiley.

May, Josef (1970). "Period Analysis and Continuous Analysis in Patinkin's Macroeconomic Model," Journal of Economic Theory, 2 (No. 1, March): 1-9.

Patinkin, Don (1956). Money, Interest, and Prices. Evanston, IL: Row Peterson.

(1959). "Keynesian Economics Rehabilitated: A Rejoinder to Professor Hicks," Economic Journal, 69 (Sept): 582-587.

(1965). Money, Interest, and Prices. 2nd ed. New York: Harper and Row.

(1972). "Samuelson on the Neoclassical Dichotomy," Canadian Journal of Economics, 5 (No. 2, May): 279-283.

(1974). "A Note on the Stability of the Metzler Phase Diagram," Journal of Political Economy, 82 (No. 3): 641-644.

(1976). Keynes' Monetary Thought: A Study of Its Development. Durham, NC: Duke University Press.

(1982). Anticipations of the General Theory? And Other Essays On Keynes. Chicago,

IL: University of Chicago Press.

(1989). Money, Interest, and Prices. 2nd ed. Abridged, with a new introduction. Cambridge, MA: MIT Press.

Pigou, A. C. (1943). "The Classical Stationary State," Economic Journal, 53: 343-351.

Samuelson, Paul A. (1968). "What Classical and Neoclassical Monetary Theory Really Was," Canadian Journal of Economics, 1 (1): 1-15.

Sidrauski, Miguel (1967). "Rational Choice and Patterns of Growth in a Monetary Economy," American Economic Review, 57 (May): 534-544.

Thalberg, Bjorn (1960). "From the 'Keynes Literature'," Statsokonomisk Tidskrift, 74 (1): 67-73 (read in translation).

Tobin, James (1958). "Liquidity Preference as Behavior Toward Risk," Review of Economic Studies, 25: 65-86. 
</ref_section> 